\section{The initial somitic phase of Myf5 expression requires neither Shh signaling nor Gli regulation}

\author{
Lydia Teboul, ${ }^{1}$ Dennis Summerbell, and \\ Peter W.J. Rigby ${ }^{2}$
}

Section of Gene Function and Regulation, The Institute of Cancer Research, Chester Beatty Laboratories, London SW3 6JB, UK

Myf5, the skeletal muscle determination gene, is first expressed in the dorso-medial aspect of the somite under the control of an element we have called the early epaxial enhancer. It has subsequently been reported that this enhancer is a direct target of Shh signaling mediated by Gli transcription factors (Gustafsson et al. 2002). We here demonstrate that activation of $M y f 5$ expression depends on neither Shh function nor an intact Gli binding site, although the Gli site is necessary for continuation of expression. We suggest that the discrepancy is due to the existence of specific interactions between the enhancer and the Myf5 promoter.

Supplemental material is available online at http://www.genesdev. org.

Received May 29, 2003; revised version accepted October 9, 2003.

Myf5 is the first myogenic regulatory factor gene to be expressed during vertebrate embryogenesis, and it acts as the determination factor for the skeletal muscle lineage (for review, see Arnold and Braun 2000). During mouse development, Myf5 expression begins in the dorso-medial aspect of the somite under the control of an element, which we have called the early epaxial enhancer (EEE), that is both necessary and sufficient for this initial phase of Myf5 transcription (Summerbell et al. 2000; Teboul et al. 2002). We noted (Teboul et al. 2002) that when isolated from the locus but not when in its normal context, the EEE drives expression at sites that correspond to anatomical locations where active Shh signaling has been shown.

Gustafsson et al. (2002) have claimed that the EEE (which they called the epaxial somite enhancer; the two terms describe exactly the same DNA sequence) is a direct target of Shh signaling mediated by transcription factors of the Gli family. They advanced three lines of evidence. First, they produced transgenic mice carrying a construct in which the EEE was juxtaposed to the pro-

[Keywords: Myf5; Shh; Gli; promoter; myogenesis; somite]

${ }^{1}$ Present address: Division of Molecular Neurobiology, MRC National Institute for Medical Research, The Ridgeway, Mill Hill, London NW7 1AA, UK.

${ }^{2}$ Corresponding author.

E-MAIL Peter.Rigby@icr.ac.uk; FAX 44-20-7352-0272.

Article and publication are at http://www.genesdev.org/cgi/doi/10.1101/ gad.1117603. moter of the herpes simplex virus thymidine kinase $(t k)$ gene, crossed them with $\mathrm{Shh}^{+/-}$mice, and observed a loss of reporter gene expression in the absence of the signal. Second, they similarly showed that inactivation of a Glibinding site in the EEE abolished expression in wild-type embryos. Third, they juxtaposed the EEE to the promoter of the chicken $\delta$-crystallin gene and showed that the Gli site mediates transcriptional activation by Shh signaling in transient transfection assays using cultured 3T3 cells.

Manipulative embryological and explant culture experiments, in both chick and mouse, have shown that some of the environmental signals that instruct cells as to their skeletal muscle fate emanate from the notochord and ventral neural tube (Pourquie et al. 1993; Munsterberg and Lassar 1995), and that the effects of these signals can be mimicked by Shh (Munsterberg et al. 1995; Borycki et al. 1999). It has been proposed that the ability of Shh to induce myogenesis depends on its control of Myf5 expression in the epaxial somite (Tajbakhsh et al. 1998; Borycki et al. 1999|. This view has been challenged by reports of epaxial somitic Myf5 expression in 10.0 days postcoitum (dpc) Danforth's short-tail mutant embryos in which the notochord has degenerated (Asakura and Tapscott 1998), in 9.5-dpc Dsh'-1- (another Shh-null mouse) embryos, in 8.5-dpc $\mathrm{Smo}^{-/-}$embryos (which lack a member of the Shh membrane receptor complex), and in the 8.5-dpc Shh ${ }^{-1-}$ mutant itself (Kruger et al. 2001; Zhang et al. 2001). To reconcile these observations, Pownall et al. (2002) have suggested that Myf5 expression in the most rostral somites is regulated by an Shhindependent mechanism.

In the present report we show that the EEE is essential for the earliest somitic expression of Myf5. This expression, and its recapitulation by EEE-containing reporters, occurs normally at all ages, and in all appropriate sites, in the absence of Shh. When an EEE containing a mutated Gli-binding site is juxtaposed to the Myf5 promoter, transcription activates correctly, although it is not properly maintained in more mature somites. Our data thus offer no support for the idea that the initial phase of Myf5 expression is controlled, either directly or indirectly, by Shh signaling. We suggest that the discrepancy between our results and those of Gustafsson et al. (2002) is due to the existence of specific interactions between the EEE and the Myf5 promoter.

\section{Results and Discussion}

The EEE directs the initial phase of somitic expression in both wild-type and $\mathrm{Shh}^{-/-}$embryos

Previous work has shown that YAC constructs containing $200 \mathrm{~kb}$ of DNA upstream of the Mrf4/Myf5 locus and BAC constructs containing $195 \mathrm{~kb}$ and $140 \mathrm{~kb}$ recapitulate all known aspects of the expression pattern of the endogenous Myf5 gene (Hadchouel et al. 2000; Carvajal et al. 2001). Although Myf5 transcripts are readily detected in the presomitic mesoderm of zebrafish and chick embryos (Coutelle et al. 2001; Hirsinger et al. 2001; Kiefer and Hauschka 2001), they cannot be seen at this location in the mouse embryo by in situ hybridization (Ott et al. 1991; Summerbell et al. 2000, 2002). Faint presomitic expression of $\beta$-galactosidase has been ob- 


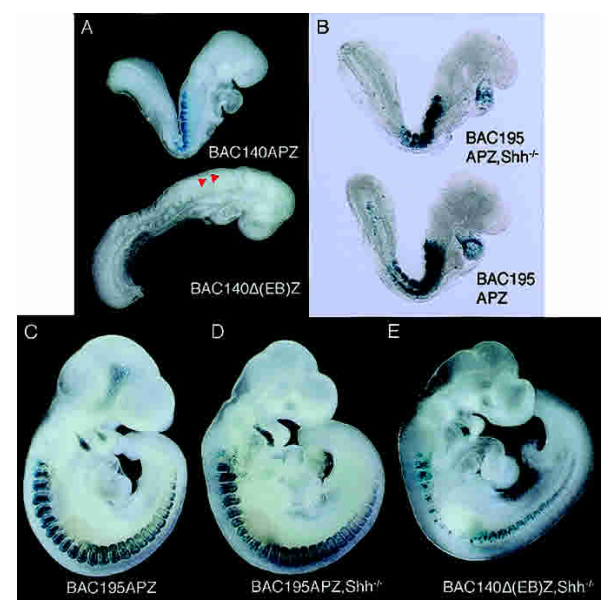

Figure 1. Characterization of EEE activity in wild-type and $\mathrm{Shh}^{-1}$ embryos. (A) In 8.5-dpc wild-type embryos, Xgal staining that recapitulates Myf5 expression is seen with BAC140APZ but not with $\mathrm{BAC} 140 \Delta(\mathrm{EB}) \mathrm{Z}$ transgenes. Arrowheads point to the two $\beta$-galactosidase-positive cells in the embryo carrying the deletion construct. (B) At $8.5 \mathrm{dpc}$, Xgal staining is seen in all somites of BAC195Z, $\mathrm{Shh}^{-/-}$embryos as well as their nonmutant littermates. Staining seen in the tail bud of the nonmutant embryo is not in the presomitic mesoderm. In 9.5-dpc nonmutant $(C)$ and $\mathrm{Shh}^{-1-}(D)$ embryos carrying BAC195Z, Xgal staining is observed in the myotomes and the dorsal and ventral dermomyotomes of all somites where Myf5 is normally expressed. (E) In 9.5-dpc BAC140D(EB)Z, Shh ${ }^{-1}$ embryos stained for $\beta$-galactosidase, transgene expression is detected in the myotomes and ventral dermomyotomes, but early epaxial expression is missing in all somites.

served in Myf5 $5^{\text {nlacz }}$ knock-in mice, which express the reporter very strongly (Cossu et al. 1996), and Myf5 transcripts are detectable in mouse presomitic mesoderm by RT-PCR (R. Gupta, D. Summerbell, and P. Rigby, unpubl.). However, we do not see consistent staining in the presomitic mesoderm with any of our many reporter constructs and thus we cannot comment on the regulation of expression at this location. Although we had shown, in the context of y200-Myf5-nlacZ, that the EEE is necessary for $M y f 5$ expression in the dorso-medial region of the newly born somite at $9.5 \mathrm{dpc}$ (Teboul et al. 2002), we had not demonstrated this at earlier times. Figure 1A shows that a BAC140APZ transgene faithfully recapitulates Myf5 expression in the somites of an 8.5dpc embryo and that deletion of the EcoRI/BamHI fragment that defines the EEE leads to the loss of all somitic expression at $8.5 \mathrm{dpc}$. Given this, and the demonstration that the EEE is sufficient for early epaxial expression at 8.5 dpc (Gustafsson et al. 2002; Teboul et al. 2002), it is clear that this is the only element required for the initial somitic phase of Myf5 expression.

To ascertain the requirement for Shh signaling, we crossed transgenic mice containing various relevant reporter constructs to $\mathrm{Shh}^{+/-}$mice (Chiang et al. 1996) and further mated them to create homozygous mutants, which are cyclopic. BAC195Z drove the same, correct expression in 8.5-dpc Shh ${ }^{-/-}$embryos as in noncyclopic (wild-type or heterozygous) littermates (Fig. 1B). Furthermore, the transgene recapitulated the normal expression pattern in all somites at $9.5 \mathrm{dpc}$ (27 somite) in nonmutant littermates and Shh ${ }^{-1-}$ embryos (Fig. 1C,D). In contrast, deletion of the EEE from BAC140APZ led to transgene expression being seen only in the ventral somitic bud, and myotome, of a 9.5-dpc (27 somite) $\mathrm{Shh}^{-1-} \mathrm{em}-$ bryo (Fig. 1E), whereas early epaxial expression was absent. We have thus shown that early epaxial expression in mutant embryos occurs in all somites at all ages between 9.5 and $11.5 \mathrm{dpc}$ (Fig. 1C,D; data not shown) and that it requires the EEE (Fig. 1E). The data eliminate the possibility that early epaxial expression in the absence of Shh signaling depends on another, uncharacterized regulatory element.

Transverse sections of a 9.5-dpc $\mathrm{Shh}^{-1-}$ embryo carrying BAC195Z showed that $\beta$-galactosidase-positive cells were present in the dorsal quadrant of the early somites, adjacent to both neural tube and ectoderm (Fig. 2, So II). The intensity of expression and the number of stained cells increased in slightly older somites, as positive cells began to appear in the ventral dermomyotome (Fig. 2, So IV). As the somites matured, strong staining was seen in the forming myotome in nuclei which were characteristically aligned at the center of the somite (Fig. 2, central panel). However, whole-mount staining and transverse sections showed that the structure of the myotome was abnormal (Fig. 2, central panel and So XIV-XXIV). Comparisons of these serial sections with those previously obtained from wild-type embryos (Summerbell et al. 2000, 2002; Teboul et al. 2002) confirmed that the expression of the transgene is correctly initiated in the early somites of $S h h^{-\gamma-}$ embryos. Although these assays are relatively insensitive to levels of expression, and we therefore cannot say that Shh signaling has no effect on the output of the EEE, it is not the case that Shh is required for enhancer activity. It is noteworthy that in $\mathrm{Myf5}^{-/-}$mice, translocation of muscle precursor cells from the dermomyotome to form the myotome is delayed for 2 to $3 \mathrm{~d}$ because in the absence of Myf5 and MyoD function, precursors are retained at the dorsal and ventral edges of the dermomyotome (Braun et al. 1994; Tajbakhsh et al. 1996). In $\mathrm{Shh}^{-/-}$embryos, the initiation of myotome formation was seen from $9.5 \mathrm{dpc}$ (Figs. 1D,E and 2), further demonstrating that there is functional

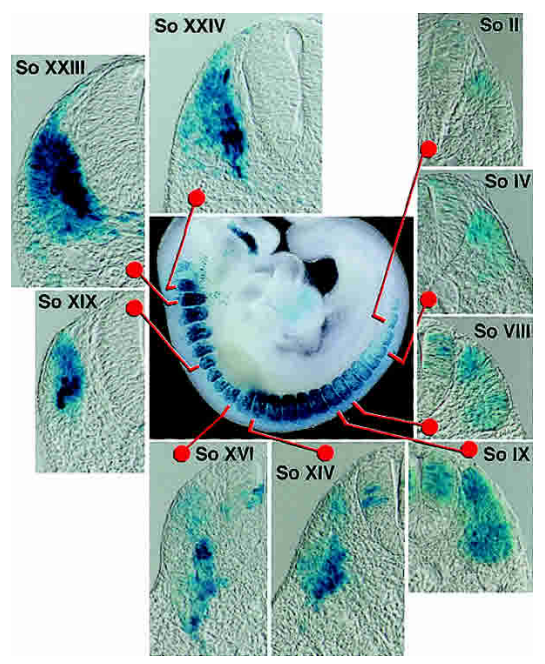

Figure 2. Transverse sections of the Xgal-stained 9.5-dpc (27 somite) BAC195Z, Shh ${ }^{-/}$embryo that is shown in Figure 1D. $\beta$-galactosidase-positive cells are detected adjacent to the dorsal neural tube in early somites (So II). Stronger expression is seen in the subsequent, older somites (So IV-IX). $\beta$-galactosidase-positive cells are also seen in the ventral dermomyotome (So IV-IX). In older somites, strongly positive cells are seen, the nuclei of which are aligned in the center of the somites (central panel and So XIV-XXIV). 


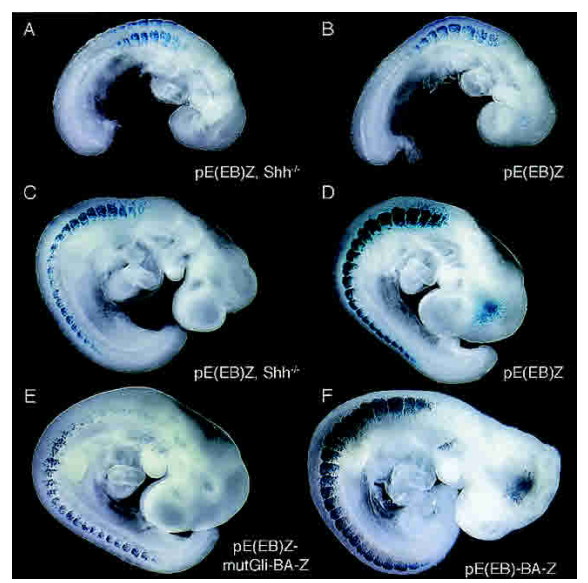

Figure 3. Role of Shh signaling and Gli-binding site in $\mathrm{pE}(\mathrm{EB}) \mathrm{Z}$ activity. Shown are 8.5-dpc $(A) \mathrm{pE}(\mathrm{EB}) \mathrm{Z}, \mathrm{Shh}^{-1-},(B)$ nonmutant pE(EB)Z, 9.5-dpc $(C) \mathrm{pE}(\mathrm{EB}) \mathrm{Z}, S h h^{->-},(D) \mathrm{pE}(\mathrm{EB}) \mathrm{Z},(E) \mathrm{pE}(\mathrm{EB})$ mutGliBA-Z, and $(F) \mathrm{pE}(\mathrm{EB})-\mathrm{BA}-Z$ embryos stained for $\beta$-galactosidase. In $\mathrm{pE}(\mathrm{EB}) \mathrm{Z}, \mathrm{Shh}^{-/-}$embryos, epaxial somitic expression is evident in all somites, most strongly at cervical/occipital levels. In wild-type embryos, the $\mathrm{pE}(\mathrm{EB}) \mathrm{Z}$ transgene directs strong expression in all epaxial somites in the absence $(D)$ or the presence $(F)$ of a positive control for transgenesis. Reporter activity is also detected in epaxial somites of $\mathrm{pE}(\mathrm{EB})$ mutGli-BA-Z, wild-type embryos but decreasing in a gradient along the caudo-rostral axis; staining disappears at occipital levels $(E)$.

Myf5 in the region of the somite in which the EEE operates.

In construct $\mathrm{pE}(\mathrm{EB}) \mathrm{Z}$, the $E c o \mathrm{RI} / \mathrm{BamHI}$ fragment that defines the EEE is juxtaposed to the Myf5 minimal promoter (Summerbell et al. 2000) driving an nlacZ reporter gene. When mice carrying this construct were crossed to $\mathrm{Shh}^{+/-}$mice, strong dorsal somitic staining was seen at $8.5 \mathrm{dpc}$ in both $\mathrm{Shh}^{-1-}$ embryos and their noncyclopic littermates (Fig. 3A,B). Transgene expression was seen in the epaxial region of somites along the entire anteroposterior axis of 9.5-dpc (26 somite) Shh ${ }^{-/-}$embryos (Fig. $3 \mathrm{C}, \mathrm{D})$ in a pattern indistinguishable from that of noncyclopic littermates.

These data show that Shh signaling is not required for the activity of the EEE when it is acting on the endogenous Myf5 promoter either in isolation or in its normal context within the Mrf4/Myf5 locus. This is the case in all somites examined between $8.5 \mathrm{dpc}$ and $11.5 \mathrm{dpc}$, and not only in cervical and occipital somites as proposed by Pownall et al. (2002). Myf5 epaxial expression is comparable in 8.5-dpc Shh ${ }^{-/-}$and $\mathrm{Smo}^{-1-}$ embryos (Zhang et al. 2001), indicating that other hedgehogs do not compensate for the absence of Shh, unless there is another, unidentified receptor. These conclusions are at variance with those of Gustafsson et al. (2002), who reported that in all somites EEE activity is strictly dependent on Shh signaling. We think it likely that this discrepancy arises from the fact that these workers used a heterologous promoter, the highly sophisticated $t k$ promoter from herpes simplex virus (Imbalzano and DeLuca 1992), which resulted in weakly expressing reporter lines (Figs. 2Ac-e and 4Aa in Gustafsson et al. 2002). It is clear that in the context of the intact locus, the EEE activates the Myf5 promoter but cannot engage productively with the Mrf4 promoter, to which it is closer (Summerbell et al. 2002; J. Carvajal and P. Rigby, unpubl.), indicating that proper transcriptional regulation requires specific interactions with its homologous promoter.
Mutation of the Gli-binding site in the EEE modifies but does not abolish enhancer activity

Gustafsson et al. (2002) identified a Gli-binding site in the EEE and claimed that it is essential for enhancer activity. We had independently identified this same site and agree that it binds Gli proteins (data not shown). We introduced into the EEE the same mutation used by Gustafsson et al. (2002; GACCACCAA to GACtgCagA), which prevents Gli binding as detected by electrophoretic mobility shift assays. The transgenic reporter constructs contained wild-type or mutant EEEs juxtaposed to the Myf5 minimal promoter together with an element that controls expression in the branchial arches as a positive control for transgenesis. The wild-type construct gave expression in all somites of a 9.5-dpc embryo (Fig. $3 \mathrm{D}, \mathrm{F})$, whereas in a 9.5 -dpc (27 somite) embryo carrying the mutant construct, staining was absent from the most rostral six or seven somites (Fig. 3E). Staining intensity decreased along the caudo-rostral axis such that very little was detected in cervical somites and none in occipital somites. In 10.5- and 11.5-dpc embryos, activity of the wild-type transgene was detected in all somites (Fig. 4A,C). In 10.5- and 11.5-dpc embryos carrying the mutant construct (Fig. 4B,D), we observed branchial arch expression driven by the control enhancer (arrows), but staining was observed only in the younger somites. We obtained similar results with another mutation (GAC CACCAA to GACCggacc) that also prevents Gli binding (data not shown). We conclude that the Gli-binding site is not required for the activation of the EEE, although it does play a role in the continuation of enhancer output during somite maturation.

\section{Ectopic expression driven by the isolated EEE does require an intact Gli-binding site}

The isolated EEE, even when juxtaposed to the homologous promoter, drives expression at several ectopic sites including the cephalic mesoderm, the posterior lateral

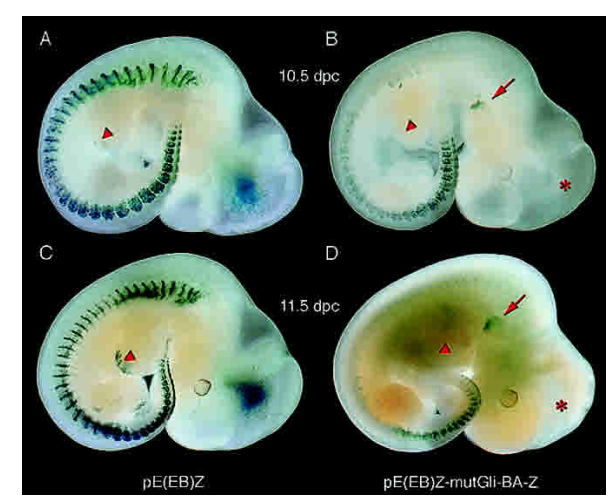

Figure 4. Mutational analysis of the Gli-binding site in the EEE. Xgal staining of $(A, B)$ 10.5- and $(C, D)$ 11.5-dpc embryos bearing $(A, C)$ the $\mathrm{pE}(\mathrm{EB}) \mathrm{Z}$ or $(B, D)$ the $\mathrm{pE}(\mathrm{EB})$ mutGli-BA-Z transgene is presented. The mutation abolishes continuation of epaxial transgene expression as somites mature (cf. $A$ to $C$ and $B$ to $D$ ), although epaxial staining remains in younger somites at all ages considered $(B, D)$. Ectopic expression in cephalic mesoderm (stars) and the lateral edge of the limb (arrowhead) seen with the isolated enhancer $(A, C)$ is eliminated by the mutation $(B, D)$. Activity of the positive control in the $\mathrm{pE}(\mathrm{EB})$ mutGli-BA-Z transgene (intergenic branchial arch element; Summerbell et al. 2000) is seen (arrows in $B$ and D). 
edge of the limb (Fig. 4, arrowheads), and nonmyogenic cells in the branchial arches (Fig. 4A,C; Teboul et al. 2002). These sites correspond to regions where active Shh signaling has been shown (Riddle et al. 1993; Ahlgren and Bronner-Fraser 1999; Schneider et al. 2001). No such ectopic expression was seen in $S_{h h^{-/-}}$embryos (Fig. $3 \mathrm{~A}, \mathrm{C}$; note absence of expression in the head mesoderm; data not shown) or in wild-type embryos carrying the Gli mutant construct (stars and arrowheads in Fig. 4B,D). These data make it quite clear that Shh signaling through the Gli-binding site is required for ectopic expression but not for the activation of the EEE in the somites.

\section{The Gli-binding site in the EEE is required for} continued enhancer activity during somite maturation

Histochemical staining patterns (Figs. 3C and 4B,D) suggest that expression directed by the transgene containing the Gli-binding site mutation is not maintained during somite maturation, but it is difficult to assess the precise effects of the mutation on enhancer activity because of the perdurance of the reporter enzyme. We therefore performed in situ hybridization experiments to detect the lacZ reporter transcripts (Hadchouel et al. 2000) in 9.5dpc embryos carrying $\mathrm{pE}(\mathrm{EB}) \mathrm{Z}$ wild-type and mutant constructs. With the wild-type construct, reporter transcripts were detected in all somites but at significantly lower intensities at rostral levels (Fig. 5A; Teboul et al. 2002), whereas with the mutant construct, they were detected in only the five to eight youngest somites (Fig. $5 \mathrm{~B}$, arrowhead). We also performed in situ hybridization experiments on $\mathrm{Shh}^{-/-}$embryos carrying BAC195Z (Fig. 5C) and on the endogenous Myf5 gene (Fig. 5D) in such mutant embryos. Although the anatomy of the cyclopic embryos is distorted, it is clear again that the EEE is

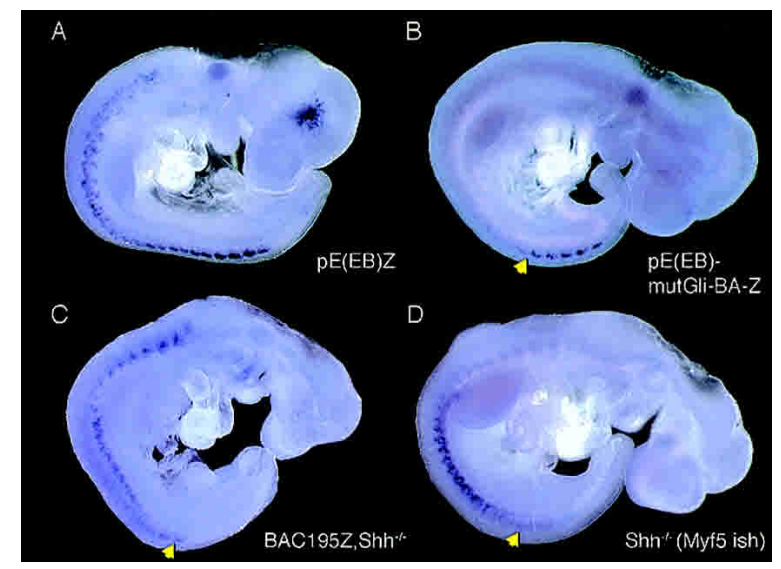

Figure 5. Analysis of reporter gene transcription. In situ hybridization of nlacZ transcripts was performed on 9.5-dpc $\mathrm{pE}(\mathrm{EB}) \mathrm{Z}(A)$, $\mathrm{pE}\left(\mathrm{EB} / \mathrm{mutGli}-\mathrm{BA}-\mathrm{Z}(B)\right.$, and BAC195Z, Shh ${ }^{-/}$embryos (C). In situ hybridization of Myf5 transcripts was performed on 9.5-dpc Shhembryos $(D)$. In wild-type $\mathrm{pE}(\mathrm{EB}) \mathrm{Z}$ embryos, nlac $Z$ transcripts are detected in all epaxial somites, although less strongly at rostral levels $(A)$. In contrast, in wild-type $\mathrm{pE}(\mathrm{EB})$ mutGli-BA-Z, nlacZ transcripts are seen predominantly in the youngest somites (arrowhead in B). In BAC195Z, Shh ${ }^{-1-}$ and Shh S $^{-1-}$ embryos, nlacZ and Myf5 transcripts, respectively, are detected in ventral dermomyotomes and in poorly developed myotomes along the rostro-caudal axis. Although corresponding $\beta$-galactosidase activity is detected by Xgal staining, both transcripts are visualized in a fuzzy pattern in the epaxial somites in the mutants (arrowheads). normally active in such mutant embryos (Fig. 5C,D, arrowheads).

We conclude that the Gli-binding site but not Shh signaling is required for continued expression in maturing cervical and occipital somites. This may reflect the fact that a protein other than Gli binds the site in vivo or the modulation of Gli activity by other signals. For example, GSK3, a component of the Wnt signaling pathway, regulates the activity of $\mathrm{Ci}$, the Drosophila counterpart of Glis (Jia et al. 2002: Price and Kalderon 2002), whereas Smads, which are involved in the transduction of TGF $\beta$ family signals, physically interact with Glis (Liu et al. 1998). However, expression appears reduced at brachial and thoracic levels in 9.5-dpc pE(EB)Z, Shh ${ }^{-1-}$ embryos (Fig. 3C). This effect is also seen using lacZ and Myf5 in situ hybridization to BAC195Z, Shh ${ }^{-1-}$, and $S h h^{-1-}$ embryos, respectively (Fig. 5C,D). The cause of this latter failure to maintain expression in the mutant is unclear. It is possible that Shh is specifically required in these somites for continuation of enhancer output, or that there is a general failure of transcription, or an induction of RNA turnover, in the dorsal part of the somites, where the relevant cells will be missing by the following day (Borycki et al. 1999).

We have shown that the earliest phase of Myf5 expression controlled by the EEE requires neither Shh signaling nor a functional Gli-binding site. The Gli site but not Shh signaling is required for the continuation of enhancer activity during somite maturation. We think that the discrepancy between our results and those of Gustafsson et al. (2002) derives from the fact that proper proper transcriptional regulation by the EEE requires the homologous Myf5 promoter.

\section{Materials and methods}

Preparation of plasmid and BAC constructs

BAC195Z and BAC140APZ (Carvajal et al. 2001) and pE(EB)Z (Teboul et al. 2002) have been described previously. Plasmids were prepared using standard recombinant DNA techniques (Sambrook and Russell 2001). The BAC140D(EB)Z construct was obtained by modification of BAC140Z using homologous recombination in bacteria (Carvajal et al. 2001). All constructs were checked by dideoxy-sequencing. Full information on all cloning steps can be obtained upon request.

\section{Production of transgenic mice and crosses}

Transgenic mice were produced by pronuclear injection of single-cell embryos from C57Bl/6JxCBA crosses as previously described (Yee and Rigby 1993). Founder mice were detected as previously described (Summerbell et al. 2000). The deletion of the EEE previously performed in a YAC-based construct (Teboul et al. 2002) was repeated in a BAC-based construct to give BAC $140 \Delta(\mathrm{EB}) \mathrm{Z}$. The $\mathrm{BAC} 140 \Delta(\mathrm{EB}) \mathrm{Z}$ reporter transgene was expressed in the dorsal somite in a pattern comparable to that driven by the y200 $\Delta$ E-Myf5-nlacZ at all stages considered $(8.5-12.5 \mathrm{dpc})$. The numbers of transgenic lines and transient embryos analyzed are summarized in Supplemental Table 1. Reporter lines were crossed with $S h h^{+/-}$ mice, and offspring were genotyped as described (Chiang et al. 1996). Males heterozygous for both the transgene and the mutant allele were crossed with $\mathrm{Shh}^{+/-}$females. Embryos from these crosses were harvested at the indicated times, and $S h h^{-/-}$embryos were identified by their characteristic cyclopia (Chiang et al. 1996). Somite identification was according to Ordahl (1993) and embryo staging to Spörle and Schugart (1997). This staging scheme takes into account the most rostral somites that have disappeared by $9.5 \mathrm{dpc}$.

Whole-mount in situ hybridization, staining for $\beta$-galactosidase activity, histology, and photomicroscopy

Whole-mount in situ hybridization, staining for $\beta$-galactosidase activity, histology, and photomicroscopy were performed as previously described (Teboul et al. 2002). 


\section{Acknowledgments}

We thank Phil Beachy for his generous gift of $S h h^{+/-}$mice and David Cox for his help with BAC manipulations. We are grateful to the staff of the ICR Biological Services Unit, particularly Albert Hallsworth, for expert animal husbandry, and to Marjorie Kipling and members of the Molecular Embryology team at The Institute of Cancer Research for their critical reading of the manuscript and helpful discussions. L.T. was supported by a Marie Curie Research Training Fellowship from the European Community and The Institute of Cancer Research. The work was supported by The Institute of Cancer Research.

The publication costs of this article were defrayed in part by payment of page charges. This article must therefore be hereby marked "advertisement" in accordance with 18 USC section 1734 solely to indicate this fact.

\section{References}

Ahlgren, S.C. and Bronner-Fraser, M. 1999. Inhibition of Sonic hedgehog signalling in vivo results in craniofacial neural crest cell death. Curr. Biol. 9: 1304-1314.

Arnold, H.H. and Braun, T. 2000. Genetics of muscle determination and development. Curr. Top. Dev. Biol. 48: 129-164.

Asakura, A. and Tapscott, S.J. 1998. Apoptosis of epaxial myotome in Danforth's short-tail (Sd) mice in somites that form following notochord degeneration. Dev. Biol. 203: 276-289.

Borycki, A.G., Brunk, B., Tajbakhsh, S., Buckingham, M., Chiang, C., and Emerson Jr., C.P. 1999. Sonic hedgehog controls epaxial muscle determination through Myf5 activation. Development 126: 4053-4063.

Braun, T., Bober, E., Rudnicki, M.A., Jaenisch, R., and Arnold, H.H. 1994. MyoD expression marks the onset of skeletal myogenesis in Myf-5 mutant mice. Development 120: 3083-3092.

Carvajal, J.J., Cox, D., Summerbell, D., and Rigby, P.W.J. 2001. A BAC transgenic analysis of the Mrf4/Myf5 locus reveals interdigitated elements that control activation and maintenance of gene expression during muscle development. Development 128: 1857-1868.

Chiang, C., Litingtung, Y., Lee, E., Young, K.E., Corden, J.L., Westphal, H., and Beachy, P.A. 1996. Cyclopia and defective axial patterning in mice lacking Sonic hedgehog gene function. Nature 383: 407-413.

Cossu, G., Tajbakhsh, S., and Buckingham, M. 1996. How is myogenesis initiated in the embryo? Trends Genet. 12: 218-223.

Coutelle, O., Blagden, C.S., Hampson, R., Halai, C., Rigby, P.W.J., and Hughes, S.M. 2001. Hedgehog signalling is required for maintenance of myf5 and myoD expression and timely terminal differentiation in zebrafish adaxial myogenesis. Dev. Biol. 236: 136-150.

Gustafsson, M.K., Pan, H., Pinney, D.F., Liu, Y., Lewandowski, A., Epstein, D.J., and Emerson Jr., C.P. 2002. Myf5 is a direct target of long-range Shh signaling and Gli regulation for muscle specification. Genes \& Dev. 16: 114-126.

Hadchouel, J., Tajbakhsh, S., Primig, M., Chang, T.H., Daubas, P., Rocancourt, D., and Buckingham, M. 2000. Modular long-range regulation of Myf5 reveals unexpected heterogeneity between skeletal muscles in the mouse embryo. Development 127: 4455-4467.

Hirsinger, E., Malapert, P., Dubrulle, J., Delfini, M.C., Duprez, D., Henrique, D., Ish-Horowicz, D., and Pourquie, O. 2001. Notch signalling acts in postmitotic avian myogenic cells to control MyoD activation. Development 128: 107-116.

Imbalzano, A.N. and DeLuca, N.A. 1992. Substitution of a TATA box from a herpes simplex virus late gene in the viral thymidine kinase promoter alters ICP4 inducibility but not temporal expression. J. Virol. 66: $5453-5463$.

Jia, J., Amanai, K., Wang, G., Tang, J., Wang, B., and Jiang, J. 2002. Shaggy/ GSK3 antagonizes Hedgehog signaling by regulating Cubitus interruptus. Nature 416: 548-552.

Kiefer, J.C. and Hauschka, S.D. 2001. Myf-5 is transiently expressed in nonmuscle mesoderm and exhibits dynamic regional changes within the presegmented mesoderm and Somites I-IV. Dev. Biol. 232: 77-90.

Kruger, M., Mennerich, D., Fees, S., Schafer, R., Mundlos, S., and Braun, T. 2001. Sonic hedgehog is a survival factor for hypaxial muscles during mouse development. Development 128: 743-752.

Liu, F., Massague, J., and Ruiz i Altaba, A. 1998. Carboxy-terminally truncated Gli3 proteins associate with Smads. Nat. Genet. 20: $325-$ 326.

Munsterberg, A.E. and Lassar, A.B. 1995. Combinatorial signals from the neural tube, floor plate and notochord induce myogenic bHLH gene expression in the somite. Development 121: 651-660.

Munsterberg, A.E., Kitajewski, J., Bumcrot, D.A., McMahon, A.P., and Lassar, A.B. 1995. Combinatorial signaling by Sonic hedgehog and Wnt family members induces myogenic bHLH gene expression in the somite. Genes \& Dev. 9: 2911-2922.

Ordahl, C.P. 1993. Myogenic lineages within the developing somite. In Molecular basis of morphogenesis (ed. M. Bernfield), pp. 165-176. John Wiley and Sons, New York.

Ott, M.O., Bober, E., Lyons, G., Arnold, H., and Buckingham, M. 1991. Early expression of the myogenic regulatory gene, myf-5, in precursor cells of skeletal muscle in the mouse embryo. Development 111: 1097-1107.

Pourquie, O., Coltey, M., Teillet, M.A., Ordahl, C., and Le Douarin, N.M. 1993. Control of dorsoventral patterning of somitic derivatives by notochord and floor plate. Proc. Natl. Acad. Sci. 90: 5242-5246.

Pownall, M.E., Gustafsson, M.K., and Emerson Jr., C.P. 2002. Myogenic regulatory factors and the specification of muscle progenitors in vertebrate embryos. Annu. Rev. Cell. Dev. Biol. 18: 747-783.

Price, M.A. and Kalderon, D. 2002. Proteolysis of the Hedgehog signaling effector Cubitus interruptus requires phosphorylation by Glycogen Synthase Kinase 3 and Casein Kinase 1. Cell 108: 823-835.

Riddle, R.D., Johnson, R.L., Laufer, E., and Tabin, C. 1993. Sonic hedgehog mediates the polarising activity of the ZPA. Cell 75: 1401-1416.

Sambrook, J. and Russell, D.W. 2001. Molecular cloning: A laboratory manual. Cold Spring Harbor Laboratory Press, Cold Spring Harbor, NY.

Schneider, R.A., Hu, D., Rubenstein, J.L.R., Maden, M., and Helms, J.A. 2001. Local retinoid signaling coordinates forebrain and facial morphogenesis by maintaining Fgf8 and Shh. Development 128: 27552767.

Spörle, R. and Schughart, K. 1997. System to identify individual somites and their derivatives in the developing mouse embryo. Dev. Dyn. 210: 216-226.

Summerbell, D., Ashby, P.R., Coutelle, O., Cox, D., Yee, S., and Rigby, P.W.J. 2000. The expression of Myf5 in the developing mouse embryo is controlled by discrete and dispersed enhancers specific for particular populations of skeletal muscle precursors. Development 127: 3745-3757.

Summerbell, D., Halai, C., and Rigby, P.W.J. 2002. Expression of the myogenic regulatory factor Mrf4 precedes or is contemporaneous with that of Myf5 in the somitic bud. Mech. Dev. 117: 331-335.

Tajbakhsh, S., Rocancourt, D., and Buckingham, M. 1996. Muscle progenitor cells failing to respond to positional cues adopt non-myogenic fates in myf-5 null mice. Nature 384: 266-270.

Tajbakhsh, S., Borello, U., Vivarelli, E., Kelly, R., Papkoff, J., Duprez, D., Buckingham, M., and Cossu, G. 1998. Differential activation of Myf5 and MyoD by different Wnts in explants of mouse paraxial mesoderm and the later activation of myogenesis in the absence of Myf5. Development 125: 4155-4162.

Teboul, L., Hadchouel, J., Daubas, P., Summerbell, D., Buckingham, M., and Rigby, P.W.J. 2002. The early epaxial enhancer is essential for the initial expression of the skeletal muscle determination gene Myf5 but not for subsequent, multiple phases of somitic myogenesis. Development 129: 4571-4580.

Yee, S.P. and Rigby, P.W.J. 1993. The regulation of myogenin gene expression during the embryonic development of the mouse. Genes \& Dev. 7: 1277-1289.

Zhang, X.M., Ramalho-Santos, M., and McMahon, A.P. 2001. Smoothened mutants reveal redundant roles for Shh and Ihh signaling including regulation of L/R symmetry by the mouse node. Cell 106: 781-792. 


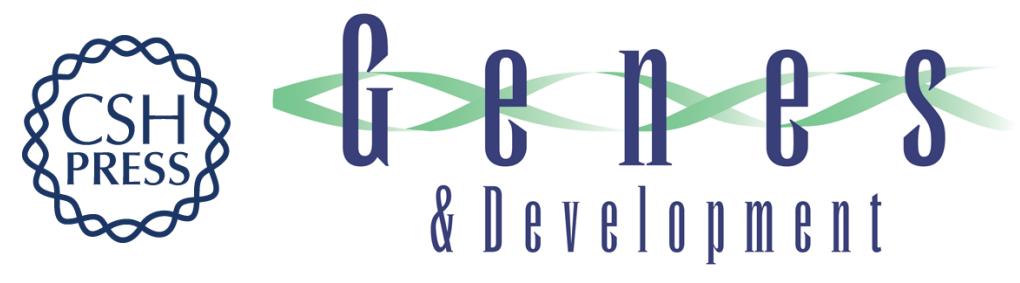

\section{The initial somitic phase of Myf5 expression requires neither Shh signaling nor Gli regulation}

Lydia Teboul, Dennis Summerbell and Peter W.J. Rigby

Genes Dev. 2003, 17:

Access the most recent version at doi:10.1101/gad.1117603

Supplemental http://genesdev.cshlp.org/content/suppl/2003/12/04/17.23.2870.DC1
Material

References This article cites 32 articles, 16 of which can be accessed free at:

http://genesdev.cshlp.org/content/17/23/2870.full.html\#ref-list-1

License

Email Alerting

Receive free email alerts when new articles cite this article - sign up in the box at the top

Service

right corner of the article or click here.

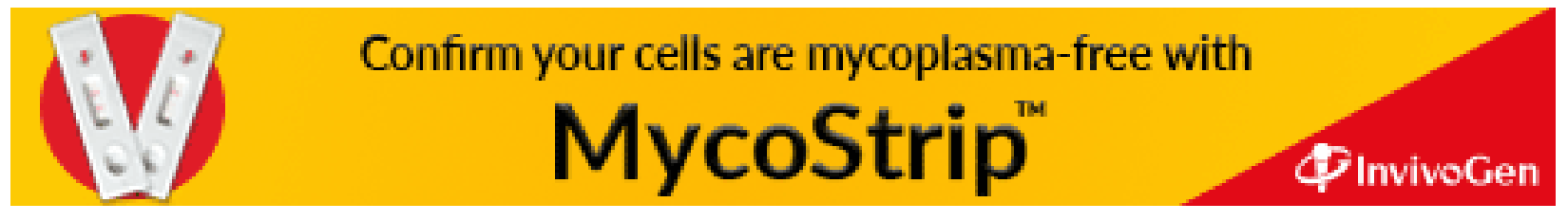

